\title{
Historical Awareness Through the Use of the WhatsApp Group Application as a Distance Learning Media
}

\begin{abstract}
Wike Silfa
History Education Study Program, School of Postgraduate Universitas Pendidikan Indonesia, West Java 40154, Indonesia.

Email: wikesilfa@gmail.com

ABSTRACT

Since the establishment of the emergency period of corona virus desease (Covid-19) in Indonesia, the policy was implemented based on government circular number 4 of 2020 which contains about the change of learning system from face-to-face system to distance learning system, namely learning from home (online). The use of communication and information technology-based learning media is a major requirement in achieving these efforts. WhatsApp as one of the most popular social media today, has full features that can be used as interactive learning media between teachers and students for distance learning. The purpose of the discussion in this paper seeks to explain the use of the WhatsApp Group application in history learning in order to foster an understanding of students' historical awareness. This study uses a naturalistic study whose presentation is based on qualitative descriptive analysis. The results show that the use of WhatsApp Group as a learning medium can create interactive and effective communication between teachers and students. Conversations through WhatsApp Group are able to stimulate active involvement both physically, mentally and emotionally of students, of course this will make it easier to provide an understanding of a historical event study, which in turn will lead to an understanding of students' historical awareness about the journey of their nation in the past and can also foster ideas. ideas for present and future life.
\end{abstract}

Keywords: Distance Learning Media, Historical Awareness, WhatsApp Group Application.

\section{INTRODUCTION}

Education and history are inseparable things. Education is a process of developing the potential of students so that they can become heirs and developers of the nation's culture. Through education, various values and excellence of the nation are introduced, studied and developed into the culture of themselves, society, and the nation in accordance with the era in which students live and develop themselves [1]. Meanwhile, history is a dialogue between past events and future developments [2]. Through history education, humans get the values of lessons contained in historical events to be used as a guide for life and inspiration for the future.

The spread of Corona Virus Disease (COVID19) not only has an impact on changes in the social and economic life of the community, but also causes changes in the world of education. This change is in the form of cancellation of the conventional face-toface learning system directly at school into a distance learning system with online mode, this is taken by educational institutions in order to implement the government's appeal through the Decree of the Minister of Education and Culture of the Republic of Indonesia regarding Circular Number 4 of 2020 concerning Policy Implementation Education in an Emergency Period of the Spread of Corona Virus Disease (Covid-19).

It is hoped that learning history in a special period does not eliminate the meaning of history learning itself. Therefore, careful learning planning is very important to prepare the teacher, such as preparing learning tools and materials and preparing learning strategy steps. The extent to which the teacher can design and shape the learning environment to be attractive to students to the extent 
that the learning process can take place. Without planning, the learning objectives will not be able to stimulate the motivation to understand students' historical awareness of the values contained in each historical event that is studied, so it possible that students will continue to think of history as a boring and uninteresting subject because the presentation of historical learning is only about memorizing past events, royal names, figures and year numbers of events [3]

In planning learning, the teacher can not only focus on delivering the material and assignments that will be given to students, but in planning history learning the teacher is expected to also focus on activities that can stimulate, trigger and inspire students so that students have inner and outer motivation so that they have encouragement to learn and follow the learning process. If students are motivated in learning history, they will be challenged to dig deeper into the learning material so that historical awareness will emerge without being forced by the teacher to understand the meaning of a historical event.

\subsection{Historical Awareness}

Historical awareness is essentially an awareness of the meaning of memory of human experience. Through historical education, human experiences in the past are reminded. Remembering means trying to experience or know again past experiences. Through history and learning from history, humans finally realize and know that the dignity and identity of a nation are shaped and perfected through and by history. Historical awareness indicators can be formulated to include: 1). Live the meaning and essence of history for the present and the future. 2). Know yourself and your people. 3). Cultivating history for the fostering of the nation's culture. 4). Maintaining the nation's historical heritage [4].

Historical awareness as the ability to understand events and value content in history shows that history is a scientific framework. One of the historical scientific frameworks includes historical events related to tridimensional (the continuity of past, present, and future events) and the values they contain in historical chronology and periodization. Chronology and periodization in history, apart from being related to actors, places, and events, also appear socio-cultural symptoms as a form of human activity. The chronological relationship and historical periodicity with socio-cultural phenomena are a source of learning in history learning.

\subsection{Distance Learning Media}

Etymologically the media comes from latin, which is the plural form of the word "medium", meaning intermediary or introduction of information between the sender to the recipient of the message. According to Heri Susanto [5] the definition of learning media is two words that are interconnected, media means teacher tools in school and learning is the process of interacting teachers and students and all components of learning. Meanwhile, Gangne and Briggs [6] said that learning media includes tools that are physically used to convey the content of teaching materials, including books, tape recorders, movies, slides, photos, images, graphics, television and computers. In other words, media is a component of learning resources or physical rides that contain instructional material in the student environment that can stimulate students to learn.

With the term media mediator shows its function and role, namely managing an effective relationship between the two main parties in the learning process, namely students and the content of the lesson. In addition, the mediator can also reflect the notion that any learning system that plays a mediating role, from teachers to the most sophisticated equipment, can be called media. In summary, media is a tool that delivers or delivers learning messages [7].

In planning the distance learning system the media also determines the success of learning activities. Good learning media is a combination of learning materials with learning tools and is part of learning resources to serve as the delivery of messages and information in learning [8]. The media in question must of course be accessible to all students and can be used as a means of support in the distance learning process. In this case the use of appropriate technology is very important to facilitate the process of interaction, communication and presentation so that learning can run well [9].

\subsection{WhatsApp Group Application.}

Today's technological developments can be used as a medium of learning and stimulate student motivation. One form of technological sophistication that can be used in distance learning to establish interactive communication between teachers and students is social networking media found on smartphones, namely the WhatsApp application. The WhatApp application is a social networking media that can connect many people in an audio-visual communication and is also supported by chat capabilities that are relatively fast compared 
to other applications, for example BBM, FB Massanger or Yahoo Massanger.

The WhattApp application is easy to install in smartphone programs, light installation data, can be created groups for certain communities, has high chat acceleration, can be used to send files, pictures, voice messages, videos, GPS, web posts / links, emojis etc. Then in WhatsApp text you can also use bold, italic and underline features which are very useful, for example for word affirmation and affirmation of certain terms. The status of receiving messages can also be seen in this application, namely a white tick for pending message alerts, and two white ticks meaning the message has been received and not read / opened, two blue ticks as a sign that the message has been received or read [10].

WhatsApp is the most popular chat application today [11]. This application is used by more than 1.5 billion users worldwide. Even according to the Sensor Tower report, WhatsApp was founded by two former Yahoo! Brian Acton and Jan Koum in 2009, became the most downloaded application on the Play Store and App Store. Based on these data it can be concluded that the students are familiar and know this application and are used to using it. WhatsApp itself also provides various features that can facilitate learning activities and one of them is the WhatsApp Group, by using the WhatsApp Group, a teacher or educator can collect students in one chat room, so that students can interact properly using text, voice notes in response to the material presented. delivered by the teacher through the features available in the WhatsApp application.

\section{METHODS}

The method used in this research is qualitative research methods. Qualitative research is also called naturalistic research because the nature of the data collected through descriptions without using measuring devices in accordance with the research field situation is natural or natural as it is without being manipulated. Research is carried out naturally, namely the actual situation to reveal a phenomenon, and not an experiment created by the research.

According to Lincoln and Guba [12], naturalistic research requires realities as a whole that cannot be understood if separated from the context. Therefore, in naturalistic research, a researcher must not do a treatment or action on the subject to be researched, meaning that a researcher examines the subject according to the actual facts that exist on the subject. Furthermore, to understand in depth about this research, the researcher needs to go to the field to make direct observations of the research subject, including conducting direct interviews and participating in learning activities with teachers and students so that they are able to obtain a comprehensive description of the object under study according to the circumstances and facts on the ground.

The subject of this study was students in class XI.IPS SMA Negeri 1 Teluk Kuantan Riau Province by observing the learning process of history subjects through class WhatsApp groups. Researchers collected data from all conversations, actions and habits that teachers and students unconsciously demonstrated during the learning process. Through direct observations made, researchers can understand the learning situation thoroughly, gain their own impressions and feel the situation of distance learning conducted through WhatsApp Group.

Then the researchers also collected data when researchers conducted interviews of teachers and students. The interview technique conducted in this study is unstructured interviews, in conducting interviews, researchers give flexibility to respondents to answer all questions. Researchers ask questions that are not limited to answers, or also called open questions, without any intervention by researchers to the answers given by respondents. These efforts are made by researchers to obtain interview results that researchers can use to get information on how the distance learning process is conducted through whatsapp application media during the Covid 19 pandemic. Furthermore, researchers compile the results of interviews chronologically and systematically so that the data obtained, ready to be used as sources that can describe the learning of history using the media application whatsapp group.

\section{RESULTS AND DISCUSSION}

This research focuses on the historical awareness of class XI.IPS students of SMA Negeri 1 Teluk Kuantan Riau in using the WhatsApp Group application as a medium for distance learning that took place during the Covid-19 pandemic. The resource person of this research is one of the teachers teaching Indonesian history subjects and several students who were randomly selected at the school.

Based on the results of interviews conducted to all sources, it is known that the group's WhatsApp application can be a medium that can support and 
facilitate communication and interaction between teachers and students during distance learning with online systems. WhatsApp has a chat feature to facilitate discussion of lessons to replace the face-toface learning system, one of which is Group WhatsApp. The feature allows multiple WhatsApp users to chat in a single chat room about learning so that when teachers send messages in the form of documents, photos, audio, videos or link links as learning lessons into a group, all members can receive and read simultaneously. Learning information can also be presented up-to-date and real-time without ads. Both teachers and students can easily view and repeat learning materials.

With the advantages that have been described by whatsApp application, the communication between teachers and students in the group WhatsApp application is expected not only to be used as a medium to provide assignments and collect student tasks but can be used more effectively in the implementation of learning activities, namely as a medium of distance learning that can connect students and teachers with an approach to active and collaborative learning models although teachers and students are only connected only through online media. Therefore, it is necessary to play an active role of teachers in opening insights, expressing logic and imaginative in learning.

In the learning process through whatsApp group observed by researchers, teachers try to provide motivation to increase students' curiosity about historical events in each material. For example, in the material about the struggle of the Indonesian nation in maintaining Indonesia's independence, the teacher sent a documentary about the guerrilla war conducted by General Sudirman, the teacher can see who the students have read and who the students are not active when the teacher sends the link. Then after that the teacher directed the students to have a discussion and question and answer about the documentary. During the discussion, the teacher gave motivation and tried to invite students to explore the meaning and value contained in the guerrilla war conducted by General Sudirman his troops. At the end of the activity the teacher invites students to conclude the results of their discussion on the material by linking the historical events they have discussed with the present life. Students are given an understanding of how high the fighting spirit of the heroes to seize san defend indonesia's independence for the sake of the next generation.

From the observations that take place learning history through the group's WhatsApp application is not just to provide knowledge about historical events to the extent of what events, who did it and where a historical event occurred. But moreover, every chat and response delivered is able to maximize the active involvement of students in discussion forums conducted during ongoing history learning, so that interactive communication between teachers and students can provide a more effective understanding of historical awareness. Barton [13] suggests that students should not only be passive recipients of historical facts, but should also learn history through active involvement in interpreting history. The results can be seen in the table of achievement of the following historical awareness indicators:

\begin{tabular}{|c|l|ll|c|}
\hline Number & \multicolumn{1}{|c|}{ Indicators } & \multicolumn{1}{c|}{ Implementation } & Result \\
\hline 1. & $\begin{array}{l}\text { Live the meaning and nature of } \\
\text { history for the present and the } \\
\text { future. }\end{array}$ & $\begin{array}{l}\text { Past experiences are used as a way to } \\
\text { solve problems that arise in the } \\
\text { present. } \\
\text { Through history students can learn } \\
\text { the values that existed in the past to } \\
\text { face the present. } \\
\end{array}$ & $\begin{array}{l}\text { History is able to build students' } \\
\text { ideas about the consequences of what } \\
\text { has been done in the present and the } \\
\text { future. } \\
\text { The past is a reference in taking } \\
\text { action in the future }\end{array}$ & $85 \%$ \\
\hline 2. & Know yourself and his people. & $\begin{array}{l}\text { History has taught students what it } \\
\text { has done. }\end{array}$ & $85 \%$ \\
\hline
\end{tabular}




\begin{tabular}{|c|c|c|c|}
\hline & & $\begin{array}{l}\text { - History tells of a group's experience } \\
\text { of its past. } \\
\text { - } \quad \text { Historical experience as a national } \\
\text { identity shaper }\end{array}$ & \\
\hline 3. & $\begin{array}{l}\text { Cultivating history for the } \\
\text { development of the nation's } \\
\text { culture. }\end{array}$ & $\begin{array}{l}\text { - History can lead students to a passion } \\
\text { for cultural values. } \\
\text { Through history students can } \\
\text { understand that a nation's civilization } \\
\text { manifests through the process of } \\
\text { history. }\end{array}$ & $85 \%$ \\
\hline 4. & $\begin{array}{l}\text { Preserving the nation's historical } \\
\text { heritage. }\end{array}$ & $\begin{array}{l}\text { By studying history students can } \\
\text { appreciate objects and sites of } \\
\text { historical relics by not damaging and } \\
\text { selling them. } \\
\text { Students actively participate in } \\
\text { maintaining the environment and } \\
\text { dissoming the historical relics that } \\
\text { are around them and those they } \\
\text { encounter in various other places. }\end{array}$ & $85 \%$ \\
\hline
\end{tabular}

From the table above can be interpreted whatsApp group application media deserves to be used as one of the media in the learning process to instill awareness of students' history. Through the use of WhatsApp application groups can be obtained opportunities for new ways of learning in raising awareness of history, so that students are motivated to learn history not just to know what events, who did them and where they happened but why something happened, what is the real event, and where it happened. The existence of effective communication in learning using this application, enabling relevant feedback, will offer effective learning opportunities [14]. In the implementation of distance learning through the WhatsApp application, teachers can facilitate learning, generate motivation, can increase curiosity and as a source of self-learning [15].

Of all the advantages of the sophistication of the group Whatsapp application technology that provides easy delivery of learning media, such as materials in the form of videos, voice notes, images and text based on the observations made, it is known that teachers and students also experience some obstacles faced, such as signal connections that are

The success of distance learning in the Covid19 pandemic era is highly dependent on the ability of teachers to stimulate students to be actively involved in pouring ideas, responses, criticism and suggestions for learning materials through the use of developing information and communication technology media. The use of the WhatsApp Group sometimes disconnected, missed incoming chats. The difference in the concept of understanding the objectives between teachers and students will also be difficult to avoid because students cannot fully feel the emotions that arise in the teacher when delivering the material, as well as the teacher, the teacher finds it difficult to understand what the student wants so it is difficult to equate the objectives in the learning activities by using WhatsApp group media.

\section{CONCLUSION}

Historical awareness is a goal of history education, namely for students to discover the importance of a series of historical events in their nation in the past. Historical awareness in this context is not just broadening knowledge, but must also be directed towards an awareness of the values relevant to the inheritance efforts of the nation's identity itself so as to give rise to the perspective that the Indonesian state is a unit that manifests through a long historical process, which in the end. managed to unite a number of small nations in a large nation, namely the Indonesian nation.

application really helps teachers in establishing interactive communication in history learning, so that through these limited learning activities, learning remains in the context of fostering the values of understanding students' historical awareness. 
Then the critical attitude of students who are conveyed during learning using the WhatsApp group application can be used as a means of finding solutions to problems that exist in the present and in the future. However, the difficulty of interacting in expressing oneself and interpreting other people's delivery as is done when communicating directly makes learning outcomes through WhatsApp group media not as effective as learning activities when carrying out conventional or faceto-face learning activities.

\section{REFERENCES}

[1]. Kemendikbud.(2012). Pemikiran tentang pembinaan kesadaran sejarah. Direktorat Jenderal Kebudayaan. Direktorat Sejarah Dan Nilai Budaya

[2]. Kochar, S.K. (2008). Teaching of History. Jakarta: Grasindo

[3]. Kochhar (2006) Teaching of History, Jakarta : Grasindo

[4]. Aman (2011) Model Evaluasi Pembelajaran Sejarah. Yogyakarta: Ombak.

[5]. Susanto, H. (2014). Seputar Pembelajaran Sejarah (Isu, Gagasan, dan Strategi Pembelajaran). Yogyakarta: Aswaja Pressindo

[6]. Arsyad,H (2013).Media Pembelajaran Sejarah. Jakarta: Grafindo.

[7]. Arsyad,H (2013).Media Pembelajaran Sejarah. Jakarta: Grafindo.

[8]. Muhson, A. (2010). Pengembangan Media Pembelajaran Berbasis Teknologi Informasi. Jurnal Pendidikan Akuntansi Indonesia, 8(2), $1-10$.

[9]. Thoms, B., \& Eryilmaz, E. (2014). How media choice affects learner interactions in distance learning classes. Computers \& Education, 75, 112-126
[10]. Amal,

Bakhrul

Khair (2019) PEMBELAJARAN BLENDED LEARNING MELALUI WHATSAPP GROUP (WAG). In: Prosiding Seminar Nasional Fakultas Ilmu Sosial Universitas Negeri Medan, 2019, Universitas Negeri Medan

[11]. Untari, Pernita Hestin. 2020. Sejarah WhatsApp aplikasi popular saat ini. Tecknookezone.com https://techno.okezone.com/read/202 0/01/18/207/2154693/sejarah-whatsAppaplikasi-chat-paling-populer-saat-ini

[12]. Moleong, L.J. (2010). Metodologi Penelitian Kualitatif. Bandung: PT. Remaja Rosdakarya. ISBN 979-514-01-5.

[13]. Martell, C. C. 2013. "Learning to teach history as interpretation: A longitudinal study of beginning teachers". The Journal of Social Studies Research,37(1), 17-31, (Online).

https://www.researchgate.net/publication/25 7268588 Learning_to_Teach_History_As_I nterpretation_A_Longitudinal_Study_of_Be ginning_Teachers.

[14]. Simon, S. (2016). Mobile instant messaging support for teaching and learning in higher education. Internet and Higher Education, 31, 32-42. https://doi.org/10.1016/j.ihed uc. 2016.06.001

[15]. Aji, S. H. (2018). Pengembangan Aplikasi Layanan Pesan Instan Whatsapp Sebagai Sumber Belajar Mandiri untuk Meningkatkan Motivasi dan Hasil Belajar Fisika Materi Pokok Efek Rumah Kaca Peserta Didik Kelas XI SMAN 1 Purwokerto. (Intergovernmental Panel on Climate Change, Ed.), Univesitas Negeri Yogyakarta. Universitas Negeri Yogyakarta, Yogyakarta. 